\title{
Improving the Acceptability of Oral Continuous Progestogens in Microdosage for Fertility Control
}

\author{
JUAN ZAÑARTU,* M.D.
}

Brit. med. F., 1967, 4, 771-772

The use of continuous microdoses of progestogens is a new concept in fertility control, and a major improvement of oral contraception. Introduced by Martinez-Manautou, CortezGallegos, and Rudel in 1964, it has aroused an increasing interest in the medical profession because of its simplicity, excellent tolerance, and effectiveness. These advantages explain its present popularity (Martinez-Manautou et al., 1966a, 1966b, 1967a, 1967b, 1967c ; Martinez-Manautou and Rudel, 1967).

Our own experience with oral continuous chlormadinone acetate $500 \mu \mathrm{g}$. in 390 young fertile women observed during 3,400 months confirms the qualities recently reported by Martinez-Manautou et al. (1967a) in a much larger group of women followed during 13,202 cycles. However, we have had a slightly higher incidence of accidental pregnancies due to therapy failure (3.3 per 100 treated women) (Zañartu et al., 1967a).

The method is particularly useful in women intolerant to conventional oral oestrogen/progestogen contraceptives. It requires a much lower dosage to inhibit fertility, without necessarily interfering with ovulation-another advantage particularly for young women wishing to plan their families (Rudel and Martinez-Manautou, 1966).

However, according to recent reports irregular uterine bleeding and menstrual cycles are significant side-effects in more than $35 \%$ of the users. In our observations, unfortunately, the incidence of irregular uterine bleeding, prolonged menstrual cycles, and amenorrhoea is high enough to be annoying. Indeed, it is a factor which causes women to discontinue therapy (Zañartu et al., 1967a).

This paper reports a simple improvement in an attempt to correct such a side-effect.

\section{Material and Methods}

Fifty young fertile women who had previously taken oral contraceptives were selected from a large group. They used conventional "combined" or "sequential" oéstrogens/progestogens, but because of poor tolerance this method was discontinued, and oral chlormadinone acetate $(0.5 \mathrm{mg}$. daily) was given instead. While they were under oestrogen/progestogen therapy their menses were regular and acceptable. The subjects were from an educated and high socio-economic group; they had completed high school and many were professional women enjoying a comfortable life.

Once the new therapy was started menstrual records were carefully kept. Patients were seen at regular intervals of three to four months, and a complete clinical and gynaecological examination was performed at each control.

Clinical and laboratory findings on subjects under continuous chlormadinone therapy have been reported (Zañartu et al., 1967a). This particular group of women were included in our study because while on oral continuous chlormadinone they presented irregular uterine bleeding (mainly hypermenorrhoea, spotting, and/or intermenstrual bleeding), prolonged cycles

- Department of Fertility, University Maternity Hospital, University of Chile Medical School, Santiago, Chile. (over 45 to 60 days), or amenorrhoea. The condition interfered with the acceptability of the method. In fact the fear of being pregnant arose when menses were delayed or because of amenorrhoea. This increased the incidence of office calls and consultations. Evidently they were annoyed by the disturbance in spite of the good tolerance of the method.

To correct uterine bleeding and regulate cycles, oral "accessory" oestrogens were given for five to seven days in each calendar month, or from the 21 st to the 25 th or the 19th to the 25th day of the menstrual cycle. In other words, one extra tablet of conjugated oestrogens (Premarin 2.5 to $5 \mathrm{mg}$. daily) was given during these days because of the good tolerance to it. However, $0.05 \mathrm{mg}$. of ethinyloestradiol was occasionally given in the same fashion when well tolerated.

The possibility that accessory oestrogens could reverse the cervical mucous changes induced by the progestogen, and nullify its contraceptive effect, was studied by post-coital Huhner-Sims tests performed at the expected ovulation time of the cycle.

\section{Results}

The effect of " accessory" oestrogen therapy in regulating menstrual cycles and making uterine bleeding more comparable with normal menses was evident, and it was satisfactory to all treated subjects. This effect was achieved without interference with the antifertility action of oral continuous contraceptive therapy with microdoses of chlormadinone acetate. In fact not a single accidental pregnancy occurred in this group during 650 months of observation.

The accessory therapy was added during five or seven days in each calendar month while the subject received one $0.5-\mathrm{mg}$. tablet of chlormadinone acetate daily. The effect of this additional therapy on uterine bleeding and cycles is summarized in the Table. It will be seen that the average duration of uterine bleeding and menstrual cycles is quite acceptable.

\begin{tabular}{|c|c|c|c|c|}
\hline \multirow{2}{*}{$\begin{array}{l}\text { No. of } \\
\text { Cases }\end{array}$} & \multicolumn{2}{|c|}{ Oestrogen Therapy } & \multirow{2}{*}{$\begin{array}{c}\text { Uterine } \\
\text { Bleeding } \\
\text { (Average) } \\
\text { Duration } \\
\text { Days }\end{array}$} & \multirow{2}{*}{$\begin{array}{c}\text { Menstrual } \\
\text { Cycles } \\
\text { (Average } \\
\text { Diventinn) } \\
\text { Days }\end{array}$} \\
\hline & Daily Dose & No. Days* & & \\
\hline $\begin{array}{r}35 \\
12 \\
3\end{array}$ & $\begin{array}{l}\text { C.O. } 2.5 \mathrm{mg} . \\
\text { C.O. } 5.0 \mathrm{mg} . \\
\text { E.O. } 0.05 \mathrm{mg} .\end{array}$ & $\begin{array}{l}5 \text { or } 7 \\
5 \\
5 \text { or } 7\end{array}$ & $\begin{array}{l}4.7(3 \text { to } 8) \\
3.9(3 \text { to } 7) \\
3.5 \text { (2 to } 6)\end{array}$ & $\begin{array}{l}29 \cdot 7 \text { (26 to } 33) \\
28.5 \text { (27 to } 32) \\
26.9 \text { (26 to } 31)\end{array}$ \\
\hline
\end{tabular}

C.O. $=$ Conjugated oestrogens (Premarin).

- Of each calendar month, or from 21 st to 25 th day or 19 th to 25 th day of the cycle

During the study 45 tests were performed 4 to 12 hours after coitus at about the expected ovulation time of the corrected cycle. In 35 tests the anti-oestrogenic effect of chlormadinone was evident: the mucus was thick, tenacious, with low spinnbarkheit, was loaded with leucocytes and cells, and did not crystallize. However, this effect was minimal in 10 tests. The physical characteristics of mucus were similar to those observed at about the 14 th or 15 th day of normal non-treated 
ovulatory cycles with good sperm tolerance. The tests were performed from 10 to 18 days after the last additional oestrogen tablet was taken.

\section{Discussion}

The incidence of uterine bleeding and menstrual cycle modifications in women receiving oral continuous chlormadinone acetate in microdoses is significant. In our experience 153 $(39.2 \%)$ out of 390 women presented some alterations in uterine bleeding while using this contraceptive method; amenorrhoea, for instance, was observed in $15 \%$ of our subjects. However, the modifications of menstrual cycles were slightly less frequent (in $147(37.6 \%)$ out of 390 treated subjects). The most annoying symptoms indeed were amenorrhoea, protonged cycles, and intermenstrual bleeding.

These alterations are apparently related to the antioestrogenic effect of the progestogen and are shown by those subjects more sensitive to such action. Furthermore, our macroscopic and microscopical observations on ovaries of subjects treated with $0.5 \mathrm{mg}$. of chlormadinone daily, who presented prolonged menstrual cycles or amenorrhoea, showed that ovulation was inhibited. A marked effect of the compound at the endometrium stroma and glands was also evident (Zañartu et al., 1967b).

These findings help us to understand why additional ostrogen therapy given for a few days for bleeding and cycle regulation could eventually reverse the effect in cervical mucus of chlormadinone $0.5 \mathrm{mg}$. daily, and yet preserve the main contraceptive effect of the therapy at other levels of the reproductive system (endometrium, endosalpinx).

The gratifying action of the accessory oestrogens by correcting uterine bleeding and regulating cycles significantly helps to improve the acceptability of this valuable contraceptive method. It has also been valuable in improving the acceptability of other progestogens in microdosage.

\section{Summary}

Fifty women presenting alterations of uterine bleeding and menstrual cycles while using oral continuous $0.5-\mathrm{mg}$. chlormadinone tablets for fertility control were given additional oral oestrogens to correct the condition. Conjugated oestrogens 2.5- or 5-mg. tablets were given for five to seven days in each calendar month. Ethinyloestradiol $0.05 \mathrm{mg}$. was also used when well tolerated. The continuous oral administration of chlormadinone tablets was maintained.

Accessory oestrogens were useful in correcting the bleeding and cycle disturbances resulting from the anti-oestrogenic effect of microdoses of oral chlormadinone without interfering with the fertility inhibition effect. It is suggested that the addition of oral oestrogens is useful to improve acceptability of continuous chlormadinone in microdoses as a contraceptive while maintaining the outstanding properties of this therapy.

Chlormadinone acetate $0.5-\mathrm{mg}$. tablets were generously donated by Syntex International (Mexico) and E. Merck-Darmstadt (Germany). We are indebted to Ayerst Laboratories Inc. (New York) for the supply of conjugated oestrogens (Premarin).

\section{REFERENCES}

Martinez-Manautou, J., Cortez, V., Giner-Velasquez, J., Aznar, R., Casasoia, J., and Rudel, H. W. (1966a). Fertil. and Steril., 17, 49. Aznar, R., Lnzano-Balderas, M., and Rudel, H. W. (1967a). Report to VIIl World Congress of the I.P.P.F. (Santiago, Chile), April.

Giner-Velasquez, J., Cortez-Gallegos, V., Casasola, J., Aznar, R., and Rudel. H. W. (1966b). Excerpta Medica International Congress

Series, No. 112, p. 157. Amsterdam. et al. (1967c). Brit. med. 3., 2, 730 . and Rudel, H. W. (1967). Excerpia Medica International Congress Series. In press.

Rudel, H. W., and Martinez-Manautou, J. (1966). Ibid., No. 111, p. 82. Amstcrdam.

Zañartu, J., Rodriguez-Moore, G., Pupkin, M., Salas, O., and Guerrero, R. (196,7a). Obstet. Ginec. lat.-amer. In press.

Rosenberg, D.. Pupkin, M., and Guerrero, R. (1967b). The Effect of Oral Continuous Chlormadinone Micro-doses in the Human Ovaries. To be published.

\title{
Transfer Factor (Diffusing Capacity) for the Lung in Simple Pneumoconiosis of Coal Workers
}

\author{
J. P. LYONS,* M.D. ; W. G. CLARKE, † M.S.R., A.R.P.S. ; A. M. HALL†; J. E. COTES, † D.M., M.R.C.P.
}

Brit. med. F., 1967, 4, 772-774

Established simple pneumoconiosis of coal workers is accompanied by a widening of the alveolar-arterial tension difference for oxygen (Brasseur, 1963) and a minimal reduction in the transfer factor (diffusing capacity) for the lung, measured by the steady state carbon monoxide method (Podlesch, Stevanowic, and Ulmer, 1966). These changes are probably due to uneven distribution of pulmonary ventilation and perfusion. The finding of a low transfer factor by this method is not necessarily evidence for a transfer defect ; this is better assessed by the single-breath carbon monoxide method, which is less susceptible to the effects of uneven distribution. With this method a number of workers have found a proportion of men with simple pneumoconiosis to have a transfer defect (for references see Nicaise, Vereerstraten, and de Clercq, 1967); the change may be accompanied by an increase in the quantity of reticulum in the lung parenchyma (Gaensler, Hoffman, and

- Pneumoconiosis Medical Panel, Cardiff.

t Pneumoconiosis Research Unit of the Medical Research Council, Llaniough Hospital, Penarth, Glamorgan.

Requests for reprints and for detalls of the physiological results should be addressed to Dr. Cotes.
Elliott, 1960). A weak association with the punctate or pinhead type of radiological opacities has been suggested by Englert and De Coster (1965). The present observations on men attending a pneumoconiosis medical panel appear to confirm this finding, which is also supported by recent work from Belgium (L. Billiet, personal communication to J. E. C.).

\section{Subjects and Methods}

Over a period of 16 months men attending the Pneumoconiosis Medical Panel, Cardiff, who were thought to have simple pneumoconiosis of a pin-head type (punctiform opacities up to $1.5 \mathrm{~mm}$. in diameter (International Labour Office, 1959)) together with some of a micronodular type (opacities of $1.5-3 \mathrm{~mm}$. in diameter) were referred to the Pneumoconiosis Research Unit for assessment. Here the chest radiographs were read in duplicate by an independent observer (W. G. C.) ; respiratory symptoms were assessed by use of the M.R.C. Respiratory Questionary (Medical Research Council, 1960); and measurements were made of ventilatory capacity, 